\title{
Detection of Galba truncatula, Fasciola hepatica and Calicophoron daubneyi environmental DNA within water sources on pasture land, a future tool for fluke control?
}

Rhys Aled Jones, Peter M. Brophy, Chelsea N. Davis, Teri E. Davies, Holly Emberson, Pauline Rees Stevens and Hefin Wyn Williams ${ }^{*}$ (1)

\begin{abstract}
Background: Increasing trematode prevalence and disease occurrence in livestock is a major concern. With the global spread of anthelmintic resistant trematodes, future control strategies must incorporate approaches focusing on avoidance of infection. The reliance of trematodes on intermediate snail hosts to successfully complete their life-cycle means livestock infections are linked to the availability of respective snail populations. By identifying intermediate snail host habitats, infection risk models may be strengthened whilst farmers may confidently apply pasture management strategies to disrupt the trematode life-cycle. However, accurately identifying and mapping these risk areas is challenging.

Methods: In this study, environmental DNA (eDNA) assays were designed to reveal Galba truncatula, Fasciola hepatica and Calicophoron daubneyi presence within water sources on pasture land. eDNA was captured using a filter-based protocol, with DNA extracted using the DNeasy ${ }^{\circledR}$ PowerSoil ${ }^{\circledR}$ kit and amplified via PCR. In total, 19 potential G. truncatula habitats were analysed on four farms grazed by livestock infected with both $F$. hepatica and C. daubneyi.
\end{abstract}

Results: Galba truncatula eDNA was identified in 10/10 habitats where the snail was detected by eye. Galba truncatula eDNA was also identified in four further habitats where the snail was not physically detected. Fasciola hepatica and C. daubneyi eDNA was also identified in 5/19 and 8/19 habitats, respectively.

Conclusions: This study demonstrated that eDNA assays have the capabilities of detecting G. truncatula, F. hepatica and C. daubneyi DNA in the environment. Further assay development will be required for a field test capable of identifying and quantifying F. hepatica and C. daubneyi infection risk areas, to support future control strategies. An eDNA test would also be a powerful new tool for epidemiological investigations of parasite infections on farms.

Keywords: Galba truncatula, Fasciola hepatica, Calicophoron daubneyi, Environmental DNA, Trematode, Snail

\footnotetext{
* Correspondence: hew05@aber.ac.uk

Institute of Biological, Environmental and Rural Sciences (IBERS), Aberystwyth University, Aberystwyth, Ceredigion, Wales, UK
}

(c) The Author(s). 2018 Open Access This article is distributed under the terms of the Creative Commons Attribution 4.0 International License (http://creativecommons.org/licenses/by/4.0/), which permits unrestricted use, distribution, and reproduction in any medium, provided you give appropriate credit to the original author(s) and the source, provide a link to the Creative Commons license, and indicate if changes were made. The Creative Commons Public Domain Dedication waiver (http://creativecommons.org/publicdomain/zero/1.0/) applies to the data made available in this article, unless otherwise stated. 


\section{Background}

Trematode parasites are amongst the most important pathogenic organisms of livestock worldwide. Among the trematode family, the liver fluke (Fasciola hepatica) infects livestock on six continents, with its disease (fasciolosis) estimated to cost the global livestock production industry $€ 2.5$ billion annually [1]. Other trematode parasites such as rumen flukes (Calicophoron daubneyi and Paramphistomum spp.), have emerged as parasites of concern in numerous temperate countries over the past decade [2-4] with climate change likely fuelling increasing trematode prevalence and disease occurrence in livestock worldwide $[5,6]$. In the continued absence of vaccines, trematodosis control in livestock is mostly via anthelmintic administration, however the sustainability of this practice is under threat due to the spread of anthelmintic resistance and limited evidence of new flukicide compounds [7].

Future control for trematodes should incorporate strategies focusing on avoidance of infection [7, 8]. Clearly, as both $F$. hepatica and $C$. daubneyi are reliant on the same intermediate snail host, Galba truncatula [9], infection risk areas for these parasites will be limited to pastures harbouring these snails. Galba truncatula snails are highly dependent on wet climatic and environmental conditions [10], and their presence and densities will vary within fields and thus, specific fluke infection risk areas will be present on farms [11]. Identifying these risk areas will strengthen trematode infection risk models [12], and support farmers to implement farm management practices such as drainage, rotational grazing and fencing and thereby reduce contact between vulnerable animals and the infective metacercariae. Obviously, fluke infection risk areas must first be accurately identified to maximise the cost-benefit of these often expensive practises.

The traditional method of physically identifying $G$. truncatula habitats by eye remains labour intensive, time consuming and is subsequently costly [12]. Novel techniques incorporating satellite imagery and GIS have recently been developed to identify potential $G$. truncatula habitats [13, 14]. However, these cannot identify the presence or intensity of snails within identified habitats. This is a major issue considering that a high percentage of seemingly suitable G. truncatula habitats may be uninhabited by the snail due to variations in habitat suitability arising due to pasture management or its environmental features [12, 15]. In addition, even in instances where G. truncatula snails are correctly identified within a habitat, their infection status will be unknown and may vary between habitats due to their previous exposure to miracidial stages of the fluke parasites and their susceptibility to parasitic infections [16].
Considering that G. truncatula snails and external infective stages of $F$. hepatica and $C$. daubneyi are predominantly found in aquatic environments, water-based environmental DNA (eDNA) assays may be a valuable tool for identifying the presence of both snail and digenean species, and subsequently to estimate the infection risk for livestock grazing a pasture. New eDNA detection techniques are increasingly being developed, optimized and adopted by researchers across a large array of fields to identify and monitor the presence of animal, plant, fungal, protist and prokaryote organisms in the environment [17]. These techniques seek to detect DNA sourced from excreted cells and tissues including skin, hairs, mucus, faeces and urine in environmental samples such as freshwater, seawater, sediments, soil and ice [17], and are regarded as having enormous potential for monitoring disease risk [18]. In recent years, eDNA techniques have been successfully developed and optimised to detect the presence of Potamopyrgus antipodarum [19] and Physa acuta snails among others [20], which suggests that the technique may be applied for other snail species, including G. truncatula. eDNA techniques have also been used within the field of parasitology, where eDNA originating from the microscopic external stages of trematode species, Ribeiroia ondatrae and Opisthorchis viverrini have been detected in freshwater [18, 21].

In this study, an eDNA assay was developed to detect the presence of G. truncatula snails in areas of pasture land. The assay was further developed to identify the presence of $F$. hepatica and $C$. daubneyi larval stages within water sources on pasture land. These assays were tested on commercial livestock farms with the aim of confirming that DNA from these organisms was present and detectable within the environment.

\section{Methods \\ eDNA capture and extraction}

A filter-based eDNA capture and extraction protocol was used throughout this study. Water samples were filtered through glass microfiber filters using a vacuum filtration kit. During this process, a filter was placed in a $5 \mathrm{~cm}$ funnel attached to a $500 \mathrm{ml}$ Buchner flask. A brake bleeding pump was used to create a vacuum within the Buchner flask, leading to the flow of water through the filter where DNA strands from the water sample were concentrated. After each filtration, the filter holder, scissors (used to cut the filter) and tweezers (used to handle filters) were soaked in $10 \%$ bleach for $5 \mathrm{~min}$ to avoid cross-contamination between samples. DNA was extracted from filter samples using the DNeasy ${ }^{\circ}$ PowerSoil ${ }^{\circ}$ kit (Qiagen, Venlo, Netherlands). Each filter, including blank controls, was homogenised using a sterile pipette tip and approximately a quarter of the filter was 
subjected to DNA extraction via the PowerSoil $^{\circledR}$ kit protocol. A quarter of the filter was extracted as this was the maximum that could be processed within a single PowerSoil ${ }^{\oplus}$ kit extraction tube.

\section{eDNA laboratory experiments}

Laboratory experiments tested two hypotheses: (i) that G. truncatula and digenean DNA would be detectable in water previously harbouring each organism; and (ii) that eDNA from these organisms could be concentrated on $2.7 \mu \mathrm{m}$ pore size glass microfiber filters. Five G. truncatula snails, collected from the field, were placed for $12 \mathrm{~h}$ in each of four plastic containers. Each container was filled with $1 \mathrm{l}$ of double distilled water. A total of $500 \mathrm{ml}$ of water from each experimental container was filtered through $5 \mathrm{~cm} 2.7 \mu \mathrm{m}$ pore size glass microfiber filters (GF/D) (Whatman plc, Maidstone, UK) at day 1, 4, 7 and 14 post-snail removal, respectively. This filtered water was then immediately re-filtered through $5 \mathrm{~cm} 0.7 \mu \mathrm{m}$ pore size glass microfiber filters (GF/F) (Whatman plc, Maidstone, UK) to test if target eDNA could escape through the larger pore sized filter. Filters were cut in half with sterile scissors and stored in $2 \mathrm{ml}$ centrifuge tubes at $-20{ }^{\circ} \mathrm{C}$ prior to DNA extraction.

An almost identical protocol was followed for the digenean eDNA experiment. Here, ten newly hatched C. daubneyi miracidia were placed in 11 of double distilled water within each of four plastic containers. Water was filtered and re filtered as described above at day 1, 4, 7 and 14 post-miracidial death. Parallel to this experiment, $C$. daubneyi miracidia were placed in water within a $5 \mathrm{~cm}$ Petri dish and their survival and tissue degradation rates at room temperature were monitored during the experimental period.

\section{Field sampling protocol}

To validate the success of the eDNA assays in identifying the presence of G. truncatula, C. daubneyi and $F$. hepatica on pasture land, water samples were taken from habitats identified to be potentially suitable for G. truncatula habitation on four Welsh farms known to have ruminants infected with both $C$. daubneyi and $F$. hepatica. These habitats included poached grassland, drainage ditches and ponds, all of which contained standing or slow-moving freshwater. Samples were taken on three visits in June, July/August and September 2017. Galba truncatula snails were collected where present from these habitats following a $10 \mathrm{~min}$ search and screened for parasitic infections using microscopy and polymerase chain reaction (PCR) methods as described by Jones et al. [9]. Mob faecal samples from each sheep flock and cattle herd grazing each farm were also collected and subjected to sedimentary FEC to identify if livestock on respective farms were shedding fluke eggs via the methods described by Jones et al. [4].

A total of $500 \mathrm{ml}$ water from the habitats was filtered through $5 \mathrm{~cm} 2.7 \mu \mathrm{m}$ pore size glass microfiber filters (GF/D) from each potential G. truncatula habitat during each visit. This filter pore size was selected after the laboratory testing showed that loss of eDNA through this filter was minimal (see results section) and it afforded the larger water filtering capacity compared to smaller pore size filters [22]. This $500 \mathrm{ml}$ water sample was collected from 10 random locations $(50 \mathrm{ml} \times 10)$ within the sampled area. Whilst sampling, care was taken to avoid disturbing the sediment in sampled water bodies as excessive humic substances in a sample would rapidly clog the filter. Following filtration, the filter was cut in half with scissors and then submerged in $500 \mu \mathrm{l}$ of CTAB buffer (10\%). The samples were stored at room temperature as described by Renshaw et al. [23]. This storage method has been shown to preserve DNA on polycarbonate track etch (PCTE) filters for 150 days [24].

\section{PCR}

Three PCR assays were designed to amplify eDNA extracted from filtered water samples. Each PCR assay was optimised to amplify species-specific G. truncatula, F. hepatica and $C$. daubneyi DNA sequences, respectively. As DNA is known to degrade rapidly in the environment, only short strands of eDNA may be present in water [18]. Thus, to increase eDNA PCR sensitivity, only primers amplifying DNA strands less than $300 \mathrm{bp}$ in length were used [25]. The ITS2 gene was chosen as the target gene for all eDNA PCR as the ITS2 sequence is known to occur in tandem repeats of often thousands of copies within the ribosomal DNA [26]. Thus, these sequences may be present in larger quantities within the environment compared to sequences from other genes [25]. Primers were designed using the Geneious software [27]. During this process, DNA sequences within a gene of interest from the target species and other related trematode species attained from the National Centre for Biotechnology Information (NCBI) database were aligned. Unique DNA sequences within each respective species' selected gene were identified and tested for their suitability as individual and paired primers using Primer3Plus software [28]. Designed primer sequences were cross-referenced with NCBI sequences via primer-BLAST to ensure species specificity to this study's target eDNA. Primers (F: 5'-GTG AGC TCT CAC GCT GCT C-3' and R: 5'-TAG AGC CCC TTG TTC TCC A-3') were designed and used to amplify 288 bp G. truncatula eDNA; primers (F: 5'-CCC CTA GTC GGC ACA CTT A-3'; and R: 5'-TAT GAA ANT AGC ATC AGA CAC ATG A-3') were designed and 
used to amplify $169 \mathrm{bp} F$. hepatica eDNA; and primers (F: 5'-GGG TGT GGC GGT AGA GTC-3'; R: 5'-CGG ACR GCA ATA GCA TCT CAA-3') were designed and used to amplify $100 \mathrm{bp}$ rumen fluke species eDNA.

For each PCR reaction, a $25 \mu \mathrm{l}$ master mix was created containing $12.5 \mu \mathrm{l}$ of Platinum ${ }^{\mathrm{Tm}}$ Green Hot Start PCR Master Mix (ThermoFisher, Hayward, USA), $0.5 \mu \mathrm{l}$ of each $10 \mu \mathrm{M}$ primer, $2 \mu \mathrm{l}$ of the extracted DNA and nuclease-free water. Each sample was subjected to PCR amplification consisting of an initial denaturation at $95{ }^{\circ} \mathrm{C}$ for 2 min followed by 40 cycles consisting of stages of denaturation $\left(30 \mathrm{~s}\right.$ at $\left.95{ }^{\circ} \mathrm{C}\right)$ annealing $(30 \mathrm{~s}$ at $61{ }^{\circ} \mathrm{C}$ ) and extension $\left(60 \mathrm{~s}\right.$ at $\left.72{ }^{\circ} \mathrm{C}\right)$, before a final 10 min extension phase at $72{ }^{\circ} \mathrm{C}$. PCR products were visualised in $2 \%$ agarose gel stained with GelRed (Biotium, Hayward, USA) along with positive and negative controls. Subsets of PCR amplicons were sequenced to validate the specificity of the eDNA identified via PCR. PCR products were subjected to clean up using the PureLink ${ }^{\ominus}$ PCR purification kit (Fisher Scientific, Waltham, USA), prior to sequencing using an ABI Prism 3100 DNA analyser (Applied Biosystems, Waltham, USA). Sequences were aligned to each specific species' reference sequence on GenBank using Geneious software [27].

\section{Results}

\section{eDNA laboratory experiment}

Galba truncatula and C. daubneyi DNA was successfully extracted and amplified from water samples in the laboratory experiments (Table 1) indicating that extracellular DNA from these species may be present and detectable in environmental samples. Calicophoron daubneyi miracidial DNA was detectable in water following full visible degradation, which had occurred within 3 days of death. This eDNA, along with G. truncatula eDNA was shown to be capable of remaining detectable in the water for 7 days after death and removal, respectively. Detectable G. truncatula and C. daubneyi DNA was shown to flow through $2.7 \mu \mathrm{m}$ pore sized glass microfiber filter, however, in each instance where DNA was amplified from $0.7 \mu \mathrm{m}$ pore sized filters, eDNA was also amplified from the $2.7 \mu \mathrm{m}$ pore sized filters.

Table 1 eDNA extraction and detection in laboratory experiments

\begin{tabular}{llllll}
\hline DNA source & Filter $(\mu \mathrm{m})$ & Day 1 & Day 4 & Day 7 & Day 14 \\
\hline G. truncatula $(n=5)$ & 2.7 & + & + & + & - \\
& 0.7 & + & - & - & - \\
C. daubneyi miracidia & 2.7 & + & + & + & - \\
$(n=10)$ & 0.7 & + & + & - & - \\
& & & & &
\end{tabular}

Key: + , positive, -, negative

\section{eDNA field survey}

Nineteen potential G. truncatula habitats were identified and sampled for eDNA on four Welsh farms (Table 2). Galba truncatula snails were identified and collected in ten of these habitats. Galba truncatula eDNA was amplified from water originating from each of these habitats (10/10 habitats) during one or more of the sampling visits. Galba truncatula eDNA was also amplified from water originating from four habitats where no G. truncatula snails were visually recorded. Sequencing of G. truncatula eDNA amplicons from each positive habitat ( $n=14)$ confirmed primer specificity as all amplicons sequenced showed > 99\% identity with the ITS2 reference sequence (GenBank: AJ296271.1).

Fasciola hepatica eDNA was amplified from water originating from five habitats, three of which contained $G$. truncatula snails infected with $F$. hepatica (Table 3). Sequencing of $F$. hepatica eDNA amplicons from each positive habitat $(n=5)$ confirmed primer specificity as all amplicons sequenced showed > 99\% identity with the ITS2 reference sequence (GenBank: AJ272053.1).

Rumen fluke eDNA was amplified from water originating from eight habitats, two of which contained G. truncatula snails infected with $C$. daubneyi (Table 3). Sequencing of each rumen fluke eDNA amplicon $(n=8)$ confirmed that the eDNA of $C$. daubneyi was present in each sample as all amplicons sequenced showed > 99\% identity with its ITS2 reference sequence (GenBank: AB042188.1).

\section{Discussion}

This paper demonstrates that eDNA assays have the capability of detecting G. truncatula, F. hepatica and $C$. daubneyi eDNA in water collected from pasture land. Overall, the assay detected G. truncatula DNA in 100\% of habitats proven to harbour the snail by eye $(n=10)$. Galba truncatula eDNA was also identified in four habitats where G. truncatula snails were not physically observed, indicating the assay has the potential to be more sensitive than the traditional method of detecting $G$. truncatula habitats by eye. Accurately identifying $G$. truncatula habitats using traditional methods may be difficult due to the variable nature of G. truncatula populations, which lead to short term variations in the snails' visible presence and population size $[10,11]$. Specialist training is therefore required to identify potential habitats and to detect and differentiate between $G$. truncatula and other similar snail species commonly observed in overlapping niches [29]. This process is impractical for farmers, whilst hiring experts in this area may be costly, even if their expertise could be supplemented with novel habitat detection methods such as GIS and satellite technology. With further refinement, an eDNA kit could offer a rapid, cheap and reliable 
Table 2 Galba truncatula eDNA detection in habitats on four Welsh farms

\begin{tabular}{|c|c|c|c|c|c|c|}
\hline \multirow[t]{2}{*}{ Habitat $^{\mathrm{a}}$} & \multicolumn{2}{|l|}{ Visit 1} & \multicolumn{2}{|l|}{ Visit 2} & \multicolumn{2}{|l|}{ Visit 3} \\
\hline & GT density & GT eDNA & GT density & GT eDNA & GT density & GT eDNA \\
\hline \multicolumn{7}{|c|}{ Confirmed G. truncatula habitats ${ }^{\mathrm{b}}$} \\
\hline A1 & High & + & Absent & - & Absent & - \\
\hline $\mathrm{A} 2$ & Absent & + & Low & - & Absent & - \\
\hline B1 & Low & - & Absent & + & Absent & - \\
\hline B2 & Low & + & Absent & + & Absent & - \\
\hline B3 & Low & + & Absent & + & Absent & - \\
\hline C1 & Low & + & Low & - & Low & + \\
\hline $\mathrm{C} 2$ & Low & + & Medium & - & Medium & + \\
\hline $\mathrm{C} 3$ & Medium & + & Absent & + & Absent & + \\
\hline D1 & Low & + & Absent & + & High & + \\
\hline D2 & Low & + & Absent & - & High & + \\
\hline \multicolumn{7}{|c|}{ Unconfirmed G. truncatula habitats } \\
\hline A3 & Absent & + & Absent & - & Absent & - \\
\hline A4 & Absent & - & Absent & - & Absent & - \\
\hline A5 & Absent & - & Absent & - & Absent & + \\
\hline A6 & Absent & - & Absent & - & Absent & - \\
\hline A7 & Absent & - & Absent & - & Absent & - \\
\hline A8 & Absent & - & Absent & + & Absent & - \\
\hline B4 & Absent & - & Absent & - & Absent & - \\
\hline B5 & Absent & - & Absent & - & Absent & - \\
\hline C4 & Absent & + & Absent & - & Absent & - \\
\hline
\end{tabular}

Abbreviations: GT G. truncatula; +, positive; -, negative

aLetter indicates farm; number indicates habitat within farm

bLow density: < 5 GT snails collected per visit; medium density: 5-15 GT; high density: > 15 GT

method of identifying G. truncatula habitats in the future. This could help farmers, veterinarians and researchers to identify fluke infection risk areas on pasture land and develop integrated control strategies that are less reliant on anthelmintics.

Fasciola hepatica and C. daubneyi eDNA was also detected in water samples collected from pasture land in this study, however, interpreting digenean eDNA detection in pasture sourced water is complex as various free-living infective and non-infective digenean stages may be the source of eDNA. Both $F$. hepatica and $C$. daubneyi eDNA was amplified from habitats where $G$. truncatula snails were not detected over three visits. In confirmed G. truncatula habitats, F. hepatica and C. daubneyi eDNA was amplified from samples collected in June, a period which is not traditionally associated with large numbers of cercariae and metacercariae being present in the study area [30]. These findings would indicate that the main source of amplified $F$. hepatica and $C$. daubneyi eDNA may be miracidia, which would likely have been abundant on sampled farms as liver and rumen fluke eggs were detected in livestock faeces throughout the study period. Laboratory-based experiments demonstrated that the eDNA assay could amplify C. daubneyi DNA from fully degraded miracidia in water. Any miracidia failing to infect an intermediate host, a frequent occurrence [31], are therefore likely to release DNA into water which may subsequently be detected. It remains unclear whether other digenean stages are major sources of eDNA. Cercariae are a likely source of eDNA, although their transformation into metacercariae may only take a few hours [32] and thus, the timeframe for their potential capture will be short. However, other sources of cercarial eDNA may include their tail, which is shed during encystment [33], and dead cercariae, a common occurrence for cercariae shed from snails due to increased risk of tissue rupture [32]. Unhatched eggs and metacercariae are unlikely to release significant amounts of DNA into the environment. Metacercarial DNA is enclosed by a protective layered shell [34, 35] which protects against desiccation, mechanical injury and toxic substances [36], whilst it has been shown that the shell of Fasciola spp. eggs must be mechanically disturbed for it to release DNA [37]. Further laboratory experiments to quantify the amount of eDNA 
Table 3 Fasciola hepatica and C. daubneyi eDNA detection in habitats on four Welsh farms

\begin{tabular}{|c|c|c|c|c|c|c|c|c|}
\hline \multirow[t]{2}{*}{ Habitat $^{a}$} & \multirow{2}{*}{$\begin{array}{l}\text { FH infections } \\
\text { in GT }\end{array}$} & \multirow{2}{*}{$\begin{array}{l}\text { CD infections } \\
\text { in GT }\end{array}$} & \multicolumn{2}{|l|}{ Visit 1} & \multicolumn{2}{|l|}{ Visit 2} & \multicolumn{2}{|l|}{ Visit 3} \\
\hline & & & FH eDNA & CD eDNA & FH eDNA & CD eDNA & FH eDNA & CD eDNA \\
\hline \multicolumn{9}{|c|}{ Confirmed G. truncatula habitats } \\
\hline A1 & Yes & No & - & - & - & - & - & - \\
\hline $\mathrm{A} 2$ & No & No & - & + & - & - & - & - \\
\hline B1 & No & No & - & - & - & - & - & - \\
\hline B2 & No & No & - & - & - & + & - & - \\
\hline B3 & No & No & - & - & - & - & - & - \\
\hline $\mathrm{C} 1$ & Yes & Yes & + & - & - & - & - & - \\
\hline $\mathrm{C} 2$ & Yes & Yes & + & + & - & - & - & - \\
\hline $\mathrm{C} 3$ & Yes & Yes & + & + & - & - & + & - \\
\hline D1 & No & No & + & - & - & - & - & - \\
\hline D2 & No & No & - & - & - & - & - & - \\
\hline \multicolumn{9}{|c|}{ Unconfirmed G. truncatula habitats } \\
\hline $\mathrm{A} 3$ & na & na & - & - & - & - & - & - \\
\hline A4 & na & na & - & + & - & - & - & - \\
\hline A5 & na & na & - & + & - & - & - & - \\
\hline A6 & na & na & - & - & - & - & + & - \\
\hline A7 & na & na & - & - & - & - & - & - \\
\hline A8 & na & na & - & - & - & + & - & - \\
\hline B4 & na & na & - & - & - & + & - & - \\
\hline B5 & na & na & - & - & - & - & - & - \\
\hline C4 & na & na & - & - & - & - & - & - \\
\hline
\end{tabular}

Abbreviations: GT G. truncatula, FH F. hepatica, CD C. daubney

a Letter indicates farm; number indicates habitat within farm

released by all free-living digenean stages will be needed to be able to fully interpret what stages of digeneans are associated with eDNA being present in pasture water.

The problematic differentiation between the non-infective miracidial and infective cercarial stages may not be a major limitation for application of eDNA assays for fluke control on farms. For example, analysis by Jones et al. [9] demonstrated that increasing numbers of liver and rumen fluke eggs shed onto a habitat was significantly associated with increasing infection prevalence of each respective fluke within G. truncatula populations. This indicates that in the presence of $G$. truncatula snails and ruminants, the detection of $F$. hepatica and $C$. daubneyi eDNA in pasture water would signal that the life-cycles of each parasite are likely to be active in the area. Further transcriptome analysis of digeneans and developments in environmental RNA (eRNA) detection in the future may enable assays to be created which may differentiate between key parasite stages by amplifying RNA from genes upregulated during a specific stage of a digenean's life-cycle [18]. These developments would allow eRNA assays to monitor levels of cercariae released from snails leading to estimations of short term infection risk on pasture. As of yet, these potential upregulated digenean genes and their associated RNA sequences have not been identified. A further problem that would need to be overcome is the unstable nature of RNA and its tendency to rapidly degrade in the environment [38]. Nevertheless, eRNA assays have been successfully designed to isolate and amplify viral RNA from river and pond water [39] and in future could be used to identify infective fluke stages in the environment.

A sampling strategy based on collecting one sample per habitat visit will likely require optimisation, as the eDNA assay did not always amplify G. truncatula eDNA during each sampling visit, where habitats were confirmed to be inhabited by G. truncatula. It is suggested that multiple subsampling is needed to increase the sensitivity of eDNA analysis [21, 40], especially when considering that low densities of G. truncatula snails on pasture land can lead to significant disease and associated losses [30]. It is acknowledged that eDNA presence in habitats is also likely to have fluctuated across sampling visits. Galba truncatula population size and behaviour varies throughout the year [10, 41], whilst miracidia and cercariae are known to favour specific environmental conditions to hatch and shed, respectively [32, 42]. 
These climatic behavioural differences may lead to variations in levels of DNA released into water by these organisms at certain periods. Subsequent studies would be advised to monitor fluctuations in eDNA detection over time and in conjunction with climatic conditions, as has been done for eDNA of other organisms [43]. Changes in climatic conditions could also affect the time window of measurable eDNA signals in the field, as temperature, sunlight and soil composition are known to affects the rate of DNA degradation [44-48], whilst rainfall could contribute to the dilution or the washing away of potential eDNA signals $[43,49]$. The latter factor could in theory lead to reduced specificity for this assay as eDNA signals may be washed to areas of pasture land where the snails do not reside. However, floating metacercariae and G. truncatula snails could potentially be washed alongside these eDNA signals and create new fluke infection risk areas $[50,51]$. Nevertheless, it would be advisable for future research to screen water sources present on pastures known not to harbour G. truncatula snails and fluke infected livestock to confirm assay specificity.

Further eDNA assay development is needed to increase sensitivity. To this end, filter pore size has a major influence on eDNA extract yields, with smaller pore sized filters associated with larger downstream DNA yields [23]. As eDNA strands are estimated to be between 1-10 $\mu \mathrm{m}$ in length on average [52] some eDNA is likely to have escaped the $2.7 \mu \mathrm{m}$ pore sized filters used for sampling in this study. However, in the laboratory experiment, in each instance where DNA was amplified from $0.7 \mu \mathrm{m}$ pore sized filters, eDNA was also amplified from the $2.7 \mu \mathrm{m}$ pore sized filters. Thus, it is assumed that a major proportion of amplifiable G. truncatula and digenean eDNA in water will be retained on $2.7 \mu \mathrm{m}$ pore-sized filters. Using $2.7 \mu \mathrm{m}$ pore sized filters is advantageous as larger volumes of water can be filtered (prior to clogging), a factor which is associated with increasing eDNA detection probability when species are present in low abundances [22]. As water from typical G. truncatula habitats such as bogs, ruts, drainage ditches and stream/pond edges is likely to be shallow and muddy, there may be increased risk of filter clogging during sampling. Clogging occurred in this study where muddy water meant that filtering the specified $500 \mathrm{ml}$ was challenging on some occasions. Prolonged dry weather could also make sampling impossible at certain times in summer if habitats dried out. Nevertheless, water is a requirement for the survival, development and transmission of these digenean parasites and their intermediate snail host [15] and thus, water-based eDNA assay should be capable of analysing most G. truncatula habitats during high risk periods for fluke transmission.
Future research is required to realise the promise of eDNA applications. For example, highly sensitive and simple loop-mediated isothermal amplification (LAMP) assays [53-55] should be incorporated into this protocol to detect lower concentrations of target eDNA whilst importantly delivering immediate field relevant data with reduced risk of assay inhibition. LAMP could be used in conjunction with site occupancy models to increase the robustness of presence data further [40]. Furthermore, quantitative PCR assays could be incorporated with the aim of quantifying infection risk if future advancements in measuring eDNA secretion and persistence are achieved [56]. Further transcriptomic and genomic discoveries may further enhance eDNA analysis capabilities allowing for DNA of specific life-cycle stages and genes associated with disease influencing traits (e.g. fluke anthelmintic resistance status, snail infection susceptibility) to be identified in the environment [57-59]. Thus, we propose these technical suggestions as the logical next steps in refining this detection method for supporting fluke control.

\section{Conclusions}

This proof of principle study demonstrates that eDNA assays have the capability of detecting G. truncatula, $F$. hepatica and $C$. daubneyi DNA in the environment. Further optimisation of this assay could lead to the development of a test capable of identifying and quantifying $F$. hepatica and $C$. daubneyi infection risk areas on pasture land. This potential eDNA test can be a powerful tool for epidemiological investigations and to improve control strategies for $F$. hepatica and $C$. daubneyi on farms. The general principles of the developed protocols can also be applied to a range of other problematic water inhabiting trematode parasites.

\section{Abbreviations \\ CTAB: Cetyltrimethylammonium bromide; eDNA: environmental DNA; FEC: Faecal egg counts; LAMP: Loop-mediated isothermal amplification; PCTE: Polycarbonate track etch}

\section{Acknowledgments \\ RAJ gratefully acknowledges the Owen Price scholarship for funding his PhD. HE gratefully acknowledges funding from Aberystwyth University's Aber Forward scheme. The project was funded by Farming Connect, Wales and the authors wish to thank Lynfa Davies and all other Farming Connect staff who assisted with the study. We also thank all the participating farmers and Dr Arwyn Edwards for his advice. IBERS receives strategic funding from BBSRC.}

\section{Funding}

The study was partly funded by Farming Connect, Wales.

\section{Availability of data and materials}

All data generated or analysed during this study are included in this published article.

Authors' contributions

RAJ, PMB and HWW conceived and designed the study. RAJ and HWW collected the samples. RAJ, CD, TD, HE and PRS analysed the samples. RAJ, PMB and HWW wrote the paper. All authors read and approved the final manuscript. 


\section{Ethics approval and consent to participate}

Not applicable.

\section{Competing interests}

The authors declare that they have no competing interests.

\section{Publisher's Note}

Springer Nature remains neutral with regard to jurisdictional claims in published maps and institutional affiliations.

Received: 22 February 2018 Accepted: 1 June 2018 Published online: 08 June 2018

\section{References}

1. Directorate-General for Research and Innovation (European Commision). A decade of EU-funded Animal Health. Luxembourg: EU publications; 2012.

2. Sanabria REF, Romero JR. Review and update of paramphistomosis. Helminthologia. 2008;45:64-8.

3. Malrait K, Verschave S, Skuce P, Loo H, Vercruysse J, Charlier J. Novel insights into the pathogenic importance, diagnosis and treatment of the rumen fluke (Calicophoron daubneyi) in cattle. Vet Parasitol. 2015;207:134-9.

4. Jones RA, Brophy PM, Mitchell ES, Williams HW. Rumen fluke (Calicophoron daubneyi) on Welsh farms: prevalence, risk factors and observations on coinfection with Fasciola hepatica. Parasitology. 2017;144:237-47.

5. Fox NJ, White PCL, McClean CJ, Marion G, Evans A, Hutchings MR. Predicting impacts of climate change on Fasciola hepatica risk. PLoS One. 2011;6:e16126.

6. Haydock LAJ, Pomroy WE, Stevenson MA, Lawrence KE. A growing degreeday model for determination of Fasciola hepatica infection risk in New Zealand with future predictions using climate change models. Vet Parasitol. 2016:228:52-9.

7. Kelley JM, Elliott TP, Beddoe T, Anderson G, Skuce P, Spithill TW. Current threat of triclabendazole resistance in Fasciola hepatica. Trends Parasitol. 2016;32:458-69.

8. Iglesias-Piñeiro J, González-Warleta M, Castro-Hermida JA, Córdoba M, González-Lanza C, Manga-González Y, Mezo M. Transmission of Calicophoron daubneyi and Fasciola hepatica in Galicia (Spain): temporal follow-up in the intermediate and definitive hosts. Parasit Vectors. 2016;9: 610.

9. Jones RA, Williams HW, Dalesman S, Ayodeji S, Thomas RK, Brophy PM. The prevalence and development of digenean parasites within their intermediate snail host, Galba truncatula, in a geographic area where the presence of Calicophoron daubneyi has recently been confirmed. Vet Parasitol. 2017;240:68-74

10. Relf V, Good B, Hanrahan JP, McCarthy E, Forbes AB, Dewaal T. Temporal studies on Fasciola hepatica in Galba truncatula in the west of Ireland. Vet Parasitol. 2011;175:287-92.

11. Charlier J, Soenen K, De Roeck E, Hantson W, Ducheyne E, Van Coillie F, et al. Longitudinal study on the temporal and micro-spatial distribution of Galba truncatula in four farms in Belgium as a base for small-scale risk mapping of Fasciola hepatica. Parasit Vectors. 2014;7:528.

12. Charlier J, Bennema SC, Caron Y, Counotte M, Ducheyne E, Hendrickx G. Towards assessing fine-scale indicators for the spatial transmission risk of Fasciola hepatica in cattle. Geospat Health. 2011;5:239-45.

13. Rapsch C, Dahinden T, Heinzmann D, Torgerson PR, Braun U, Deplazes P, et al. An interactive map to assess the potential spread of Lymnaea truncatula and the free-living stages of Fasciola hepatica in Switzerland. Vet Parasitol. 2008;154:242-9.

14. De Roeck E, Van Coillie F, De Wulf R, Soenen K, Charlier J, Vercruysse J, et al. Fine-scale mapping of vector habitats using very high resolution satellite imagery: a liver fluke case-study. Geospat Health. 2014;8:671-83.

15. Moens R. Factors affecting Lymnaea truncatula populations and related control measures. J Med Appl Malacol. 1991;3:73-84.

16. Rondelaud D. Variabilité interpopulationelle de l'infestation fasciolienne chez le mollusque Lymnaea truncatula Müller. Influence du contact préalable de la population avec le parasite. Bull Soc Zool Fr. 1993;118:185-93.

17. Thomsen PF, Willerslev E. Environmental DNA - an emerging tool in conservation for monitoring past and present biodiversity. Biol Cons. 2015; 183:4-18.
18. Huver JR, Koprivnikar J, Johnson PTJ, Whyard S. Development and application of an eDNA method to detect and quantify a pathogenic parasite in aquatic ecosystems. Ecol Appl. 2015;25:991-1002.

19. Goldberg CS, Sepulveda A, Ray A, Baumgardt J, Waits LP. Environmental DNA as a new method for early detection of New Zealand mudsnails (Potamopyrgus antipodarum). Freshw Sci. 2013;32:792-800.

20. Klymus KE, Marshall NT, Stepien CA. Environmental DNA (eDNA) metabarcoding assays to detect invasive invertebrate species in the Great Lakes. PLoS One. 2017;12:e0177643.

21. Hashizume H, Sato M, Sato MO, Ikeda S, Yoonuan T, Sanguankiat S, et al. Application of environmental DNA analysis for the detection of Opisthorchis viverrini DNA in water samples. Acta Trop. 2017;169:1-7.

22. Moyer GR, Díaz-Ferguson E, Hill JE, Shea C. Assessing environmental DNA detection in controlled lentic systems. PLoS One. 2014;9(9):e103767.

23. Renshaw MA, Olds BP, Jerde CL, McVeigh MM, Lodge DM. The room temperature preservation of filtered environmental DNA samples and assimilation into a phenol-chloroform-isoamyl alcohol DNA extraction. Mo Ecol Resour. 2015;15:168-76.

24. Wegleitner BJ, Jerde CL, Tucker A, Chadderton WL, Mahon AR. Long duration, room temperature preservation of filtered eDNA samples. Conserv Genet Resour. 2015:7:789-91.

25. Deagle BE, Eveson JP, Jarman SN. Quantification of damage in DNA recovered from highly degraded samples - a case study on DNA in faeces. Front Zool. 2006;3:11.

26. Prokopowich CD, Gregory TR, Crease TJ. The correlation between rDNA copy number and genome size in eukaryotes. Genome. 2003;46:48-50.

27. Kearse M, Moir R, Wilson A, Stones-Havas S, Cheung M, Sturrock S, et al. Geneious Basic: an integrated and extendable desktop software platform for the organization and analysis of sequence data. Bioinformatics. 2012;28: 1647-9.

28. Untergasser A, Nijveen $H$, Rao X, Bisseling T, Geurts R, Leunissen JAM. Primer3Plus, an enhanced web interface to Primer3. Nucleic Acids Res. 2007;35:71-4.

29. Macan TT. A key to the British fresh- and brackish-water gastropods, with notes on their ecology. 4th ed. Ambleside: Freshwater Biological Association; 1977

30. Ollerenshaw CB. The ecology of the liver fluke (Fasciola hepatica). Vet Rec 1959;71:957-63.

31. Smith G, Grenfell BT. The influence of water temperature and $\mathrm{pH}$ on the survival of Fasciola hepatica miracidia. Parasitol. 1984;88:97-104.

32. Dreyfuss G, Vignoles P, Rondelaud D. The mud snail (Galba truncatula) Ecology, parasitism and control. Saarbrücken: Lambert Academic Publishing; 2015.

33. Køie M, Nansen P, Christensen NØ. Stereoscan studies of rediae, cercariae, cysts, excysted metacercariae and migratory stages of Fasciola hepatica. Z Parasitenk. 1977;54:289-97.

34. Singh KS, Lewert RM. Observations on the formation and chemical nature of metacercarial cysts of Notocotylus vrbanensis. J Infect Dis. 1959;104:138-41.

35. Lengy J. Study on Paramphistomum microbothrium Fischoeder, 1901, a rumen parasite of cattle in Israel. Bull Res Coun Israel (Sect. B). 1960;9:71130.

36. Dixon KE. The structure and histochemistry of the cyst wall of the metacercaria of Fasciola hepatica L. Parasitology. 1965:55:215-26.

37. Calvani NED, Windsor PA, Bush RD, Slapeta J. Scrambled eggs: A highly sensitive molecular diagnostic workflow for Fasciola species specific detection from faecal samples. PLoS Negl Trop Dis. 2017;11:e0005931.

38. Barnes MA, Turner CR. The ecology of environmental DNA and implications for conservation genetics. Conserv Genet. 2016;17:1-17.

39. Jothikumar N, Sobsey MD, Cromeans TL. Development of an RNA extraction protocol for detection of waterborne viruses by reverse transcriptase quantitative PCR (RT-qPCR). J Virol Methods. 2010;169:8-12.

40. Schmidt BR, Kéry M, Ursenbacher S, Hyman OJ, Collins JP. Site occupancy models in the analysis of environmental DNA presence/absence surveys: a case study of an emerging amphibian pathogen. Methods Ecol Evol. 2013;4:646-53.

41. Rondelaud D, Mage C. Limnée tronquée et molluscicides. Bull Group Tech Vét. 1988;336:69-76.

42. Chryssafidis AL, Fu Y, De Waal T, Mulcahy G. Standardisation of egg-viability assays for Fasciola hepatica and Calicophoron daubneyi: a tool for evaluating new technologies of parasite control. Vet Parasitol. 2015;210:25-31.

43. Buxton AS, Groombridge JJ, Zakaria NB, Griffiths RA. Seasonal variation in environmental DNA in relation to population size and environmental factors. Sci Rep. 2017;7:46294. 
44. Crecchio C, Stotzky G. Binding of DNA on humic acids: effect on transformation of Bacillus subtilis and resistance to DNase. Soil Biol Biochem. 1998;30:1061-7.

45. Cai P, Huang Q, Zhang X, Chen H. Adsorption of DNA on clay minerals and various colloidal particles from an Alfisol. Soil Biol Biochem. 2006:38:471-6.

46. Barnes MA, Turner CR, Jerde CL, Renshaw MA, Chadderton WL, Lodge DM. Environmental conditions influence eDNA persistence in aquatic systems. Environ Sci Technol. 2014;48:1819-27.

47. Strickler KM, Fremier AK, Goldberg CS. Quantifying effects of UV-B, temperature, and $\mathrm{pH}$ on eDNA degradation in aquatic microcosms. Biol Conserv. 2015;183:85-92.

48. Tsuji S, Ushio M, Sakurai S, Minamoto T, Yamanaka H. Water temperaturedependent degradation of environmental DNA and its relation to bacterial abundance. PLoS One. 2017;12:e0176608.

49. Song JW, Small MJ, Casman EA. Making sense of the noise: the effect of hydrology on silver carp eDNA detection in the Chicago area waterway system. Sci Total Environ. 2017:605:713-20.

50. Rondelaud D, Dreyfuss G, Bouteille B, Darde ML. Changes in human fasciolosis in a temperate area: about some observations over a 28-year period in central France. Parasitol Res. 2000;86:753-7.

51. Rondelaud D, Hourdin P, Vignoles P, Dreyfuss G. The contamination of wild watercress with Fasciola hepatica in central France depends on the ability of several lymnaeid snails to migrate upstream towards the beds. Parasitol Res. 2005;95:305-9.

52. Turner $C R$, Barnes $M A$, X $\mathrm{CCY}$, Jones $\mathrm{SE}$, Jerde $\mathrm{CL}$, Lodge $\mathrm{DM}$. Particle size distribution and optimal capture of aqueous macrobial eDNA. Meth Ecol Evol. 2014;5:676-84.

53. Notomi T, Okayama H, Masubuchi H, Yonekawa T, Watanabe K, Amino N, et al. Loop-mediated isothermal amplification of DNA. Nucleic Acids Res. 2000; 28:e63.

54. Ai L, Li C, Elsheikha HM, Hong SJ, Chen JX, Chen SH, et al. Rapid identification and differentiation of Fasciola hepatica and Fasciola gigantica by a loop-mediated isothermal amplification (LAMP) assay. Vet Parasitol. 2010;174:228-33.

55. Arifin Ml, Höglund J, Novobilský A. Comparison of molecular and conventional methods for the diagnosis of Fasciola hepatica infection in the field. Vet Parasitol. 2016;232:8-11.

56. Nathan $L M$, Simmons $M$, Wegleitner BJ, Jerde $C L$, Mahon AR. Quantifying environmental DNA signals for aquatic invasive species across multiple detection platforms. Environ Sci Technol. 2014:48:12800-6.

57. Adema CM, Hillier LW, Jones CS, Loker ES, Knight M, Minx P, et al. Whole genome analysis of a schistosomiasis-transmitting freshwater snail. Nat Comm. 2017:8:15451.

58. Cwiklinski K, Dalton JP, Dufresne PJ, La Course J, Williams DJL, Hodgkinson J, et al. The Fasciola hepatica genome: gene duplication and polymorphism reveals adaptation to the host environment and the capacity for rapid evolution. Genome Biol. 2015;16:71.

59. Shokralla S, Spall JL, Gibson JF, Hajibabaei M. Next-generation sequencing technologies for environmental DNA research. Mol Ecol. 2012;21:1794-805.

Ready to submit your research? Choose BMC and benefit from:

- fast, convenient online submission

- thorough peer review by experienced researchers in your field

- rapid publication on acceptance

- support for research data, including large and complex data types

- gold Open Access which fosters wider collaboration and increased citations

- maximum visibility for your research: over $100 \mathrm{M}$ website views per year

At BMC, research is always in progress.

Learn more biomedcentral.com/submissions 